\title{
Intercropping cover crops with a poplar short rotation coppice: Effects on nutrient uptake and biomass production
}

\author{
Nicola Silvestri, ${ }^{1}$ Vittoria Giannini, ${ }^{2}$ Daniele Antichi ${ }^{1}$ \\ ${ }^{1}$ Department of Agriculture, Food and Environment, University of Pisa; ${ }^{2}$ Institute of Life Sciences, Scuola \\ Superiore Sant'Anna di Studi Universitari e di Perfezionamento, Pisa, Italy
}

\begin{abstract}
The risks of soil erosion and nutrient leaching can be considered appreciable in short rotation coppices especially in the first growth phases because of the absence of any plant cover. The temporary intercropping with legumes or grasses used as cover crops can help to overcome these environmental issues. The present research work aims to evaluate the effects of the introduction of cover crops in a short rotation poplar (Populus deltoides W. Bartram ex Marshall) with two-year harvest cycle. The plantation was located in a Typic Xerofluvent, silty-loam soil of the coastal Central Italy. Two different species of cover crops, Trifolium subterraneum L. (TS) and Lolium perenne L. (LP), were compared along with an untreated control, colonised by spontaneous vegetation (CO). Several plant and soil parameters were evaluated: the above ground biomass and nutrient accumulation for the three different soil cover types, the nitrate and water content in two soil layers $(0.00-0.30$ and $0.30-0.60 \mathrm{~m})$, the poplar yield and nutrient content in branches and leaves.

TS returned to the soil about $70 \mathrm{~kg} \mathrm{ha}^{-1}$ of nitrogen at the end of its biological cycle, thanks to the high $\mathrm{N}$ content (over $2 \%$ ) and to the noticeable amount of dry matter produced $\left(3.46 \mathrm{tha}^{-1}\right.$ of dry matter). This value was considerably higher than those of the LP $\left(23 \mathrm{~kg} \mathrm{ha}^{-1}\right.$ of $\left.\mathrm{N}\right)$ or $\mathrm{CO}\left(10 \mathrm{~kg} \mathrm{ha}^{-1}\right)$. The different amount of nitrogen returned to the soil affected both nitrate concentration in topsoil $(0.00-0.30 \mathrm{~m})$ and accumulation of nitrogen in poplar organs. Concerning phosphorous, the differences among treatments were less evident and the amount of $\mathrm{P}$ returned to the soil ranged from $2(\mathrm{CO})$ to $10(\mathrm{TS}) \mathrm{kg} \mathrm{ha}^{-1}$. However, the effect of soil cover type on $\mathrm{P}$ uptake in poplar was still appreciable. Generally,
\end{abstract}

Correspondence: Nicola Silvestri, Department of Agriculture, Food and Environment, University of Pisa, Italy. E-mail: nicola.silvestri@unipi.it

Key words: Populus deltoides; Trifolium subterraneum; Lolium perenne; bioenergy crops; agro-forestry system.

Received for publication: 5 February 2017.

Revision received: 22 October 2017.

Accepted for publication: 26 October 2017.

CCopyright N. Silvestri et al., 2018

Licensee PAGEPress, Italy

Italian Journal of Agronomy 2018; 13:934

doi:10.4081/ija.2018.934

This article is distributed under the terms of the Creative Commons Attribution Noncommercial License (by-nc 4.0) which permits any noncommercial use, distribution, and reproduction in any medium, provided the original author(s) and source are credited. the soil water content was slightly affected by the soil cover types. Indeed, the differences between the cover crops and the control became significant only in the shallowest soil layer and over the summer season. In the first year, LP induced a significant decrease in poplar yield (10.1 t ha $\mathrm{t}^{-1}$ of dry matter) in comparison with TS $\left(14.7 \mathrm{tha}^{-1}\right)$ and $\mathrm{CO}\left(13.4 \mathrm{tha}^{-1}\right)$, whereas in the second year there were no significant differences among treatments due to the weak regrowth of cover crops.

These results show how to make it feasible a long lasting coexistence between cover crops and SRC, a clever design of agro-forestry systems is therefore needed.

\section{Introduction}

Short rotation coppice (SRC) management includes the establishment of closely spaced stands of fast growing trees and the application of intensive cultivation practices such as repeated harvesting using short cutting cycles, regeneration of subsequent crops via sprouts or suckers and the use of a high degree of mechanisation (Hytönen, 1995; Kauter et al., 2003; Laureysens et al., 2004). However, one of the hindrances to a wider development of this energy source is the possible impact on the environment and on landscape that an increasing spread of biomass crops could cause (Roedl, 2010).

Generally, the SRC cultivation is supposed to be environmental friendly in comparison with the traditional row crops (Rowe et al., 2009; Langeveld et al., 2012). The reduced frequency of tillage operations (often limited to the stand plantation phase) and the high level of soil cover, ensured by the high plant density and development, as well as by the thick litter originated by the fallen leaves, are all factors able to limit sediment losses by protecting soil from the raindrop impact, increasing water infiltration and reducing run-off speed. On the other hand, the restrained use of fertilisers and pesticides in SRC cultivation reduces pollution risks also for ground water (Dimitriou et al., 2009). However, the risks of erosion and nutrient leaching can be substantial in the first growing stages of the tree crops because of the absence of an adequate protective canopy and also in the months following the harvest because of the soil compaction along wheel tracks produced by high-weight harvesting machines (Nisb et al., 2011; Vanguelova and Pitman, 2011; Bergante et al., 2015).

In this case, the use of cover crops can represent a useful agronomic measure since it can provide and maintain an appreciable soil cover especially during the winter, when the rainfall erosivity is high and the soil is otherwise bare (Malik et al., 2000; BlancoCanqui et al., 2015). Cover crops can protect soil from water erosion also thanks to the anchoring action of their root systems that can bind soil aggregates either physically (especially in the case of grass cover crops), and chemically, through the release of root 
exudates with colloidal properties (Laloy and Bielders, 2010).

Moreover, cover crops can offer other benefits by increasing the organic matter content and nutrient availability in the soil (Lal, 2009; Mazzoncini et al., 2011), by reducing the nitrate leaching (Quemada et al., 2013), by favouring the telluric cenosis development (Sapkota et al., 2012; Berthrong et al., 2013; Blanco-Canqui et al., 2015), by attracting beneficials (Nicholls and Altieri, 2012) and also by reducing the competition effects from weeds (CorreHelloua et al., 2011). Finally, the cover crop intercropping increased the capability of soil to withstand the traffic by agricultural machinery during the wet season, particularly during SRC harvest times.

It is important to choose species with a complementary biological cycle respect to that of the companion SRC species and/or to manage intercropping in order to minimise, as far as possible, negative effects of competition. In poplar SRC, the critical period for weed control, i.e. the weed free interval to prevent significant yield loss, is quite long (60-70 days) and it begins 20-30 days after planting (Otto et al., 2010). At this regard, the interaction of cover crops with water and nutrient availability in the soil should be carefully evaluated, but also competition for light and space can play an important role (Sage, 1999). Nitrogen starving or nitrogen-fixing plants, quantity and quality of produced biomass, decomposition dynamics of residues, evapotranspiration rate, and weed suppressiveness are all cover crop's aspects that can affect significantly the growth of the companion SRC crops (Willey, 1979).

Another trait to be considered in the cover crop choice is the capability of the species to remain in cultivation for more years thanks to their perennial nature or to the self-propagation capabil- ity by means of specialised reproductive organs (stolons, rhizomes, etc.), or thanks to the self-re-seeding attitude.

The aim of this study was to evaluate the suitability of intercropping with two different multiannual cover crops (i.e. Trifolium subterraneum L. and Lolium perenne L.) in a poplar short rotation coppice plantation in comparison to the no-sowing inter-row management.

\section{Materials and methods}

\section{Experimental site}

The hybrid poplar plantation was located at the Centro di Ricerche Agro-Ambientali of University of Pisa situated in the

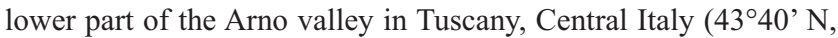
$10^{\circ} 19^{\prime}$ E, 2 m a.m.s.l.). The soil (Typic Xerofluvent, USDA classification) is a silty-loam and had previously been almost continuously grown with maize (Zea mays L.). The main physical-chemical characteristics in the 0.00-0.30 m layer were the following: clay

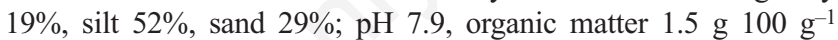

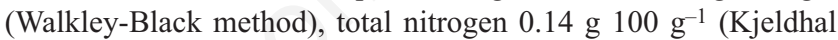
method) and assimilable phosphorus $20.5 \mathrm{mg} \mathrm{kg}^{-1}$ (Olsen method).

Climatic conditions are representative of Mediterranean coastal areas, with average annual values of cumulative rainfall and mean temperature of $826 \mathrm{~mm}$ and $15^{\circ} \mathrm{C}$, respectively. Figure 1 shows the climatic trend during the experimental period (years 2013 and 2014).
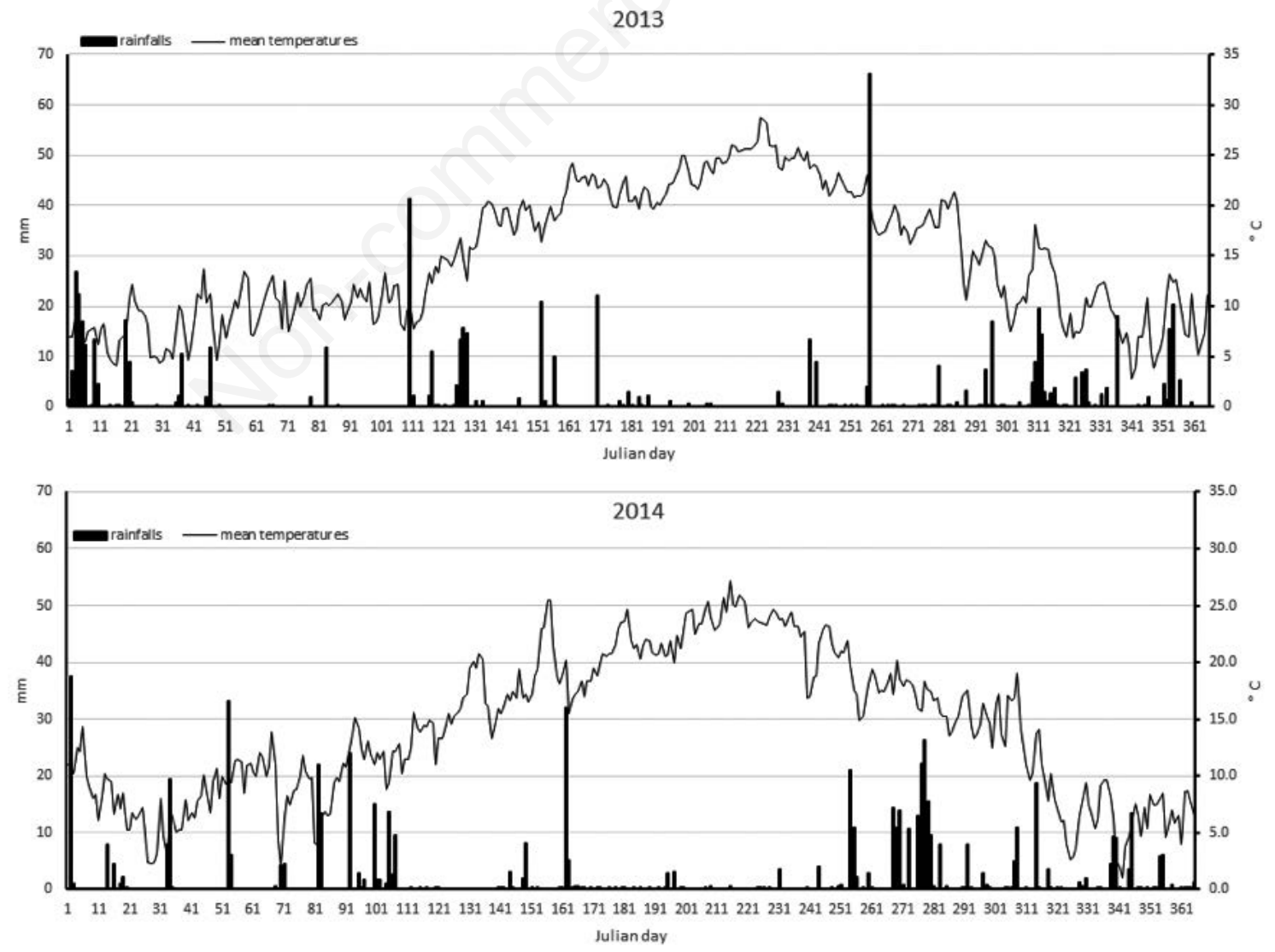

Figure 1. Mean temperatures and rainfalls recorded in the years 2013 and 2014. 


\section{Field experiment set-up}

The soil preparation was carried out in autumn (mouldboard ploughing) and in spring (harrowing). A liquid multinutrient fertiliser was applied before the plantation $\left(0.6 \mathrm{tha}^{-1}\right)$, equivalent to 48-63-120 kg ha ${ }^{-1}$ of N-P-K. The poplar grove (Populus deltoides W. Bartram ex Marshall, cv LUX) was planted on $29^{\text {th }}$ March 2012 using one-year-old dormant cuttings with a density of 8000 plants $\mathrm{ha}^{-1}(2.5 \mathrm{~m}$ inter-row and $0.5 \mathrm{~m}$ on the row $)$. In the first year, natural vegetation was mechanically controlled by two cuttings carried out on $3^{\text {rd }}$ May and on $4^{\text {th }}$ September. Neither top-dressing fertilisation nor irrigation was foreseen. On $2^{\text {nd }}$ October, the experimental plots $(25 \times 20 \mathrm{~m})$ were laid out and broadcast sown with two multiannual cover crop species: i) a self-re-seeding legume, subterranean clover (Trifolium subterraneum L., cv Clare, $35 \mathrm{~kg}$ seeds $\mathrm{ha}^{-1}$, with thousand seed weight equal to $9.1 \mathrm{~g}$ ) hereinafter named TS and a perennial grass, ryegrass (Lolium perenne L., cv Argo, 30 $\mathrm{kg}$ seeds $\mathrm{ha}^{-1}$, with thousand seed weight equal to $2.7 \mathrm{~g}$ ) hereinafter named LP. The plots used as untreated control (without cover crop) were left to normal colonisation by the natural flora (CO). At the end of spring (on $27^{\text {th }}$ May), when the cover crops had already reached the peak of their vegetative growth, a cut was carried out on all treatments to mitigate the competition for water and nutrients against the poplar and to allow the formation of dead mulch.

In this way, the competition between cover crops and poplar was minimised both because during the period following the plantation (the most sensitive for poplar) there was any cover crop and because after the cover crop sowing, the poplar was under the winter dormancy (from November to early April in our climatic region). Therefore, considering that all the covers (TS, LP and CO) were cut at the end of May, the overlapping with the biological cycle of poplar was very short (April and May).

\section{Data collection and processing}

Nitrate and water soil content were monthly monitored over the main poplar-growing season (from June to October) for the two soil layers, $0.00-0.30$ and $0.30-0.60 \mathrm{~m}$ depth. The soil samples were weighed twice (before and after oven drying at $60^{\circ} \mathrm{C}$ until constant weight) to determine the soil humidity and then sent to the laboratory for the determination of nitrate content (ion chromatography method, Dx-500 ion chromatograph; Dionex, Sunnyvale, CA). On the same dates, samples of poplar branches and leaves were taken to evaluate the $\mathrm{N}$ and $\mathrm{P}$ content within the plant tissues. The plant material (about $25 \mathrm{~kg}$ d.m.) was randomly collected from four different plants for each experimental plot and oven-dried at $60^{\circ} \mathrm{C}$ until constant weight to determine the dry matter content. The dried samples were ground to $1 \mathrm{~mm}$ and used for nutrient analyses following digestion of $200 \mathrm{mg}$ of plant material by $\mathrm{H}_{2} \mathrm{SO}_{4} / \mathrm{H}_{2} \mathrm{O}_{2}$ (Bremner, 1965). $\mathrm{N}$ concentration was determined according to the Kjeldahl method, while P concentration was determined with the molybdenum blue method using a Perkin Elmer Lambda 25 spectrophotometer (Giannini et al., 2015). At the peak of the cover crop's growth, one $1 \times 1 \mathrm{~m}$ wide destructive sample was taken from each experimental plot to evaluate the above ground biomass and the nutrient content of the cover crop and weed plants. The samples were oven-dried at $60^{\circ} \mathrm{C}$ until constant weight and, after weighting, the samples were milled and analysed as above-mentioned.

Poplar plant density was measured over a $30 \mathrm{~m}$ linear distance on $12^{\text {th }}$ July 2013. At harvest maturity (on $18^{\text {th }}$ December 2013 and on $15^{\text {th }}$ December 2014), two representative transects of four consecutive poplar plants were collected for each replicate. The fresh weights of the plants were recorded on the field using a forestry scale and one subsample was taken to determine the humidity and $\mathrm{N} / \mathrm{P}$ content (Kjeldahl and molybdenum blue in spectrophotometry method, respectively). Biomass yield per hectare was calculated relating the weight of the four plants to the plant density values measured for each plot.

Data were analysed with ANOVA according to a randomised complete block design, with the soil cover type as unique factor replicated three times (with each elementary plot being of a size of about $500 \mathrm{~m}^{2}$ ). The Duncan honest significant difference test was used for post-hoc means comparison at the $0.05 p$-level. The Bartlett's test and the Shapiro-Wilk test were performed to test the homogeneity of error variances and the normality of residual distribution, respectively (Gomez and Gomez, 1984). The N and P concentration data were transformed in arcsine or natural logarithm to fulfil the assumptions of ANOVA (version 9.1; SAS Institute Inc., Cary, NC, USA).

\section{Results and discussion}

\section{Cover crop biomass and nutrient accumulation}

The natural flora species identified at the end of May on the plots used as control (without cover crops) are reported in Table 1. The identified weeds were almost entirely dicotyledonous species. In terms of dry weight, the most represented species was Symphyotrichum squamatum (Spreng.) G.L. Nesom (53\%) followed by Chenopodium album L. (11\%) and Amaranthus retroflexus $\mathrm{L}$. (7\%). In the untreated control, total weed biomass was about $0.75 \mathrm{t} \mathrm{ha}^{-1}$ of dry matter (Table 2), a value significantly lower than the biomass produced by cover crops in TS and LP. T. subterraneum $\left(3.46 \mathrm{t} \mathrm{ha}^{-1}\right.$ ) showed an almost double growth than L. perenne $\left(1.79 \mathrm{t} \mathrm{ha}^{-1}\right)$. Both the cover crops were able to hinder the development of natural plants, with the result that the TS and LP plots were weed-free at the cutting time.

Table 1. The list of the spontaneous vegetation present on the plots used as control (without cover crops) and the percentage (on dry weight basis) of their corresponding biomass.

\begin{tabular}{|c|c|c|}
\hline Species & $\begin{array}{l}\text { Botanical } \\
\text { family }\end{array}$ & $\begin{array}{c}\text { Dry } \\
\text { weight (\%) }\end{array}$ \\
\hline $\begin{array}{l}\text { Symphyotrichum squamatum } \\
\text { (Spreng.) G.L. Nesom }\end{array}$ & Compositae & 53 \\
\hline Chenopodum album L. & Amaranthaceae & 11 \\
\hline Amaranthus retroflexus $\mathrm{L}$. & Amaranthaceae & 7 \\
\hline Sonchus arvenis L. & Compositae & 6 \\
\hline Senecio vulgaris $\mathrm{L}$. & Compositae & 4 \\
\hline Alopecurus myosuroides Huds. & Poaceae & 3 \\
\hline Polygonum aviculare $\mathrm{L}$. & Polygonaceae & 3 \\
\hline Verbena officinalis L. & Verbenaceae & 3 \\
\hline Calystegia sepium (L.) R. Br. & Convolvoluceae & 3 \\
\hline Convolvolus arvensis $\mathrm{L}$. & Convolvoluceae & 2 \\
\hline Mercurialis annua L. & Euphorbiaceae & 1 \\
\hline Veronica hederifolia L. & Verbenaceae & 1 \\
\hline Capsella bursa-pastoris (L.) Medik. & Brassicaceae & 1 \\
\hline Anagallis arvensis L. & Primulaceae & 1 \\
\hline Papaver rhoeas L. & Papaveraceae & 1 \\
\hline
\end{tabular}


Nitrogen concentration (Table 2) in TS aboveground biomass

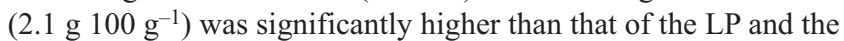
$\mathrm{CO}$, whose concentrations was about 1.3-1.4 g $100 \mathrm{~g}^{-1}$. Nitrogen accumulated in the aboveground biomass of the legume species (about $74 \mathrm{~kg} \mathrm{ha}^{-1}$ ) was decidedly greater than that returned either by LP $\left(23 \mathrm{~kg} \mathrm{ha}^{-1}\right)$ or by CO $\left(10 \mathrm{~kg} \mathrm{ha}^{-1}\right)$.

No significant difference was found among treatments with respect to the $\mathrm{P}$ concentration in above ground biomass, ranging from 0.23 (LP) to $0.30 \mathrm{~g} 100 \mathrm{~g}^{-1}$ (CO), with the level of biomass production being the main determinant of the amount of phosphorus returned to the soil with the cover cutting (from 2 to $10 \mathrm{~kg} \mathrm{ha}^{-1}$ of P) (Table 2).

The nutrient concentrations measured for the two cover crop species fell within the range reported in literature (Talamucci, 2002; Munkholm and Hansen, 2012) whereas the aboveground biomass produced was lower than the productivity of the two species in single cropping reported by others studies (Frenda et al., 2009; Munkholm and Hansen, 2012). The long-lasting shading conditions due to poplar leaves fallen at soil level during the winter period and to the new leaves produced by the poplar at the beginning of the growing season are likely the main reasons behind the limited development of the cover crops in our conditions. For this reason, the amount of nutrients returned to the soil with the cover crops cutting was smaller than that found by other Authors. This was especially significant in the case of $\mathrm{N}$ for TS, which is well known to fix up to $180 \mathrm{~kg} \mathrm{ha}^{-1}$ of nitrogen into the soil (White et al., 2000).

\section{Soil nitrate and water content}

The temporal trends of nitrate concentration in the soil as affected by the three treatments are depicted in Figure 2. The concentrations measured for the TS plots in the $0.00-0.30 \mathrm{~m}$ soil layer were significantly higher than those observed for the other two soil cover types in three different dates: $3^{\text {rd }}$ June, $18^{\text {th }}$ July and $27^{\text {th }}$ August (Figure 2A). On the contrary, the LP plots showed a reduction in nitrate content also in comparison with the control both on $18^{\text {th }}$ and $27^{\text {th }}$ August.

This pattern can be explained by considering two different processes partially overlapping. The first one linked to the increased nitrate availability in TS plots due to the activity of $\mathrm{N}_{2}$-fixing bacteria, able to justify the initial high concentration within the TS plots a few days after the cover crop cutting. The second one was the natural increase in nitrate content due to the mineralisation of soil organic matter that becomes considerable during the summer season and it was well drawn by the nitrate trend recorded in the $\mathrm{CO}$ plots where the amount of the plant biomass returned to the soil was almost negligible. The scattering of cover crop residues can interact with the usual nitrate dynamics within the shallowest soil layer leading to different effects in relation to the composition of cover crop biomass (Cohan et al., 2014). In the case of LP, it is likely that the high $\mathrm{C}: \mathrm{N}$ ratio of the biomass caused the immobilisation of nitrates produced by the organic matter mineralisation, thus reducing their availability in the soil. Conversely, the presence of plant residues with a low $\mathrm{C}: \mathrm{N}$ ratio, such as in the case of TS, might have increased the nitrate availability and enhanced the mineralisation process.

These differences tended to disappear in the $0.30-0.60 \mathrm{~m}$ soil layer (Figure 2B) where the nitrate content values were statistically equivalent among the three soil cover types. Our explanation was that the plant residues were not able to reach such depth in absence of deep tillage operations and thus they did not affect the soil nitrogen availability.

Overall, the nitrate content at a depth of $0.00-0.30 \mathrm{~m}$ was higher than in the $0.30-0.60 \mathrm{~m}$ soil layer, although the dynamics over time were similar between the two soil layers.

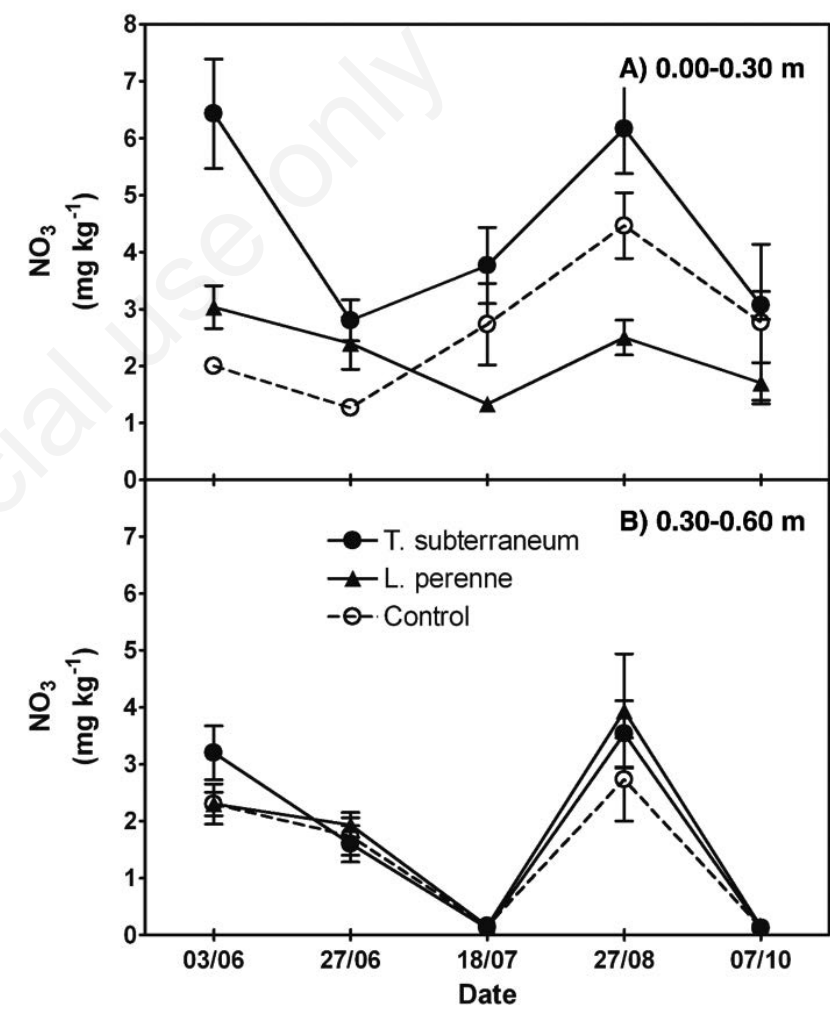

Figure 2. Soil nitrate content measured at five different dates in two soil layers $(A=0.00-0.30 \mathrm{~m}$ and $B=0.30-0.60 \mathrm{~m})$ as affected by the soil cover type: Trifolium subterraneum (TS), Lolium perenne (LP) and the untreated control (CO). Vertical bars represent the standard errors of the mean.

Table 2. Above ground biomass dry weight, nutrient ( $\mathrm{N}$ and $\mathrm{P}$ ) content and uptake as affected by the soil cover type: Trifolium subterraneum (TS), Lolium perenne (LP) and the untreated control (CO).

\begin{tabular}{|c|c|c|c|c|c|}
\hline Soil cover type & $\begin{array}{c}\text { Above ground biomass } \\
\text { t d.m. ha } \text { ha }^{-1}\end{array}$ & $\begin{array}{l}\text { N concentration } \\
\text { g } 100 \mathrm{~g}^{-1}\end{array}$ & $\begin{array}{l}\text { N uptake } \\
\text { kg ha }^{-1}\end{array}$ & $\begin{array}{l}\text { P concentration } \\
\text { g } 100 \mathrm{~g}^{-1}\end{array}$ & $\begin{array}{l}\text { P uptake } \\
\mathrm{kg} \mathrm{ha}^{-1}\end{array}$ \\
\hline TS & $3.46^{\mathrm{a}}$ & $2.14^{\mathrm{a}}$ & $74.2^{\mathrm{a}}$ & $0.29^{\mathrm{a}}$ & $10.2^{\mathrm{a}}$ \\
\hline LP & $1.79^{b}$ & $1.28^{b}$ & $23.3^{b}$ & $0.23^{\mathrm{a}}$ & $4.0^{\mathrm{b}}$ \\
\hline $\mathrm{CO}$ & $0.75^{c}$ & $1.39^{b}$ & $10.6^{\mathrm{b}}$ & $0.30^{\mathrm{a}}$ & $2.1^{\mathrm{b}}$ \\
\hline$P$ value & 0.0019 & 0.0456 & 0.0049 & 0.1024 & 0.0056 \\
\hline
\end{tabular}

${ }^{\mathrm{a}-c}$ Within each factor, letters indicate significant differences $\mathrm{P}<0.05$ (Duncan's test). 
The cover type also influenced the soil water content. In the 0.00-0.30 m soil layer (Figure 3A), the control plot always gave the lowest values, often less than $15 \%$ of soil humidity (w/w) whereas the presence of a cover crop resulted in an increase in the soil water content irrespective of the species. This means that the larger soil cover ensured by the cover crop residues was able to keep a higher soil humidity level in comparison with $\mathrm{CO}$ but also that the differences in the biomass composition and yield between TS an LP did not influence significantly the soil water content. The residual effect of the cover crops on soil humidity seemed to be significant during the warm season when the high temperatures enhanced the evaporation process (on $18^{\text {th }}$ July and $27^{\text {th }}$ August) and especially in the days immediately following rainstorms when the water in the soil was not drained or evaporated yet (on $27^{\text {th }}$ August). Therefore, we argue that the reduction of soil evaporation level due to the protective effect of the cover crop mulch (Smith et al., 1987) allowed retaining a higher humidity level only temporarily (in summer season and after a rainstorm) and only limited to the shallowest soil layer. Indeed, the soil water content in the plots with/without cover crops tended again to converge along with the temperature decrease occurring from late summer, as reported in other studies carried out in colder regions (Aronsson, 2000).

In the $0.30-0.60 \mathrm{~m}$ soil layer, no significant differences were observed among the treatments (Figure 3B) and the fluctuations within the same treatment were very limited over time (no more than two w/w percentage points). These results might be related to the above-mentioned loose nature of the soil and to the possible rising of water for capillarity action. Actually, the water table level in the experimental area is quite shallow ranging over the year from -1.20 and $-0.60 \mathrm{~m}$ a.m.s.l. (Silvestri et al., 2001).

\section{Poplar biomass and nutrient uptakes}

The nitrogen content in the branches and the leaves (Figure 4A and B) was significantly higher for poplar plants grown on the plots with TS than on the other soil cover types, with the only exception of the first sampling date ( $3^{\text {rd }}$ June), when all treatments were equivalent. The $\mathrm{N}$ concentrations in LP poplar were always the lowest since $18^{\text {th }}$ July, even if statistically equivalent to the control. Only the $\mathrm{N}$ content in the LP-leaves collected on the last sampling date $\left(7^{\text {th }}\right.$ October) was significantly lower than that of CO.

This pattern was consistent with the trend of the nitrate concentration in the shallowest soil layer discussed above, where the TS and LP plots showed the highest and lowest availability of the nitrogen soluble form, respectively. Other Authors confirmed the positive correlation in poplar between fertilisation and nitrogen uptake (Stolarski et al., 2013; Ceotto et al., 2016).

Generally, the nitrogen content, whether in the branches or in the leaves, tended to decrease along with the poplar-growing season. In fact, initial values of about $2.1-2.6 \%$ nitrogen in the branches (Figure 4A) and about $5.6-5.9 \%$ in the leaves (Figure 4B) decreased to $0.5-07 \%$ and $1.5-2.5 \%$ respectively, at the last sampling date. This means that the rising soil nitrate content observed at end of August did not produce an increase of poplar $\mathrm{N}$ uptake presumably because the senescence process in poplar was already started. Anyway, the observed values of nitrogen content can be considered consistent with those reported in literature for different species of poplar at harvest time (Kauter et al., 2003; Pellis et al., 2004; Ceotto et al., 2016; Giannini et al., 2017).

About the phosphorus content (Figure 5A and B), the results confirmed partially the nitrogen pattern although with less marked effects. The differences among treatments were statistically significant only for the central dates of the sampling period (i.e., on $27^{\text {th }}$ June, $18^{\text {th }}$ July and $27^{\text {th }}$ August) when the P concentration in TS-

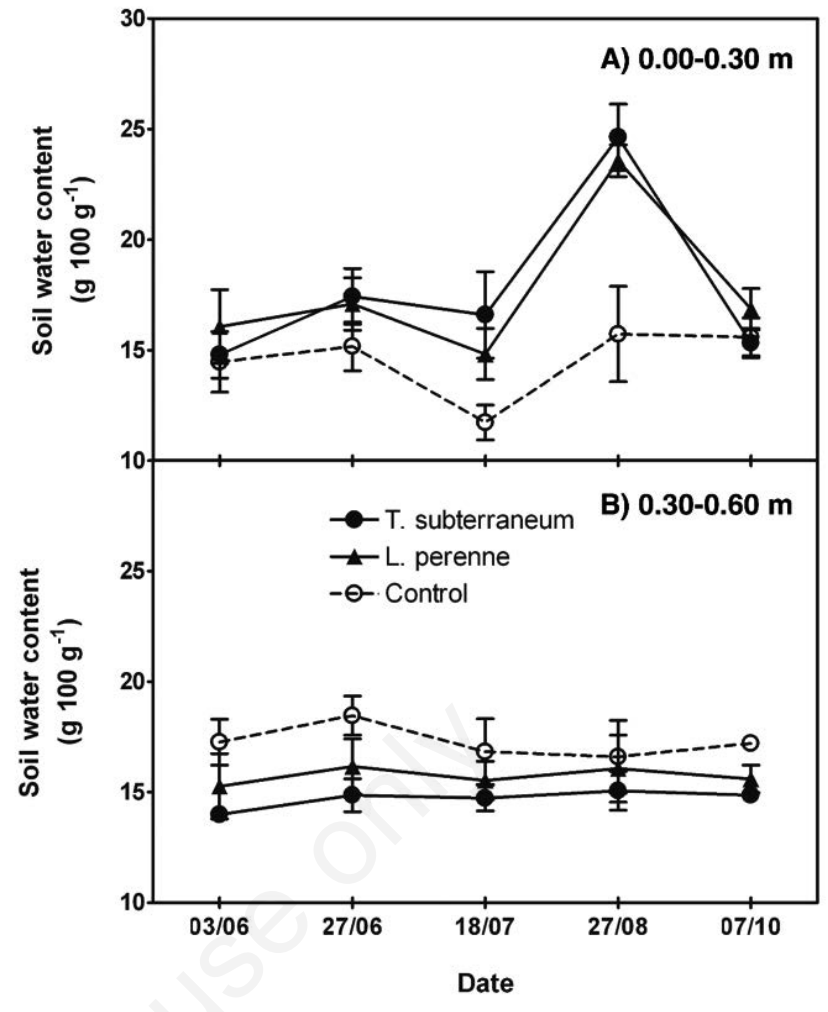

Figure 3. Soil water content at five dates in two soil layers $(A=$

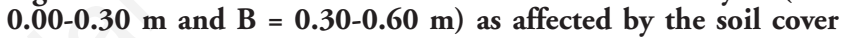
type: Trifolium subterraneum (TS), Lolium perenne (LP) and the untreated control (CO). Vertical bars represent the standard errors of the mean.

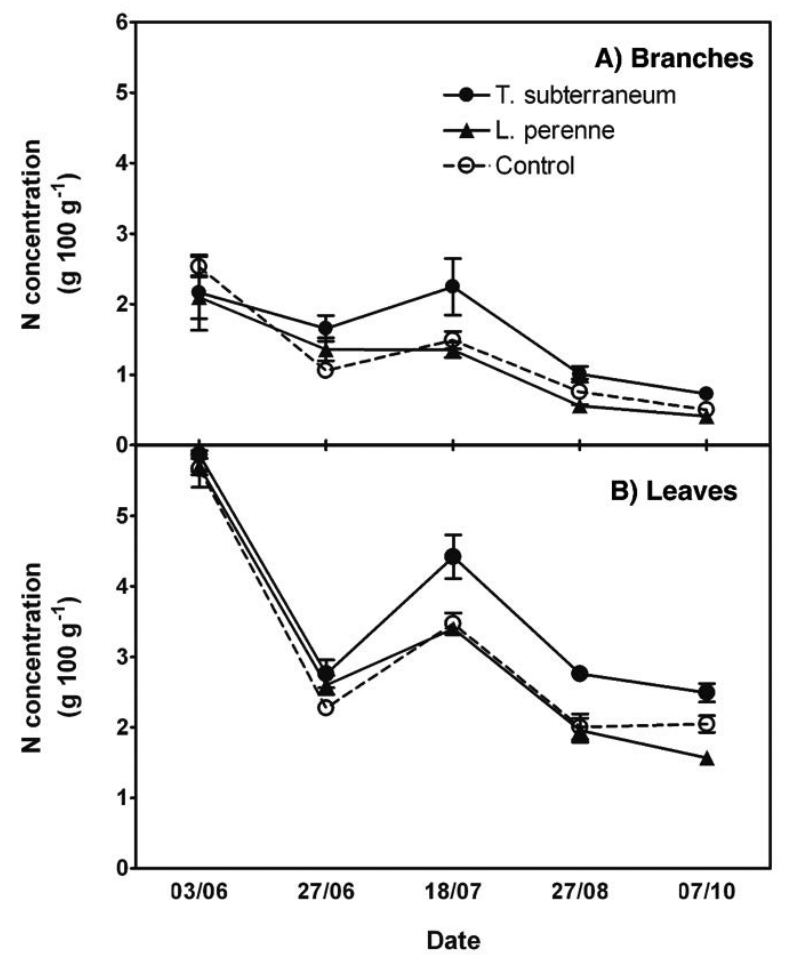

Figure 4. Nitrogen content of poplar branches (A) and leaves (B) at five different dates as affected by the soil cover type: Trifolium subterraneum (TS), Lolium perenne (LP) and the untreated control (CO). Vertical bars represent the standard errors of the mean. 
and CO-poplar plants showed higher values in comparison with the LP-poplar ones. The negative effect of LP on P concentration might have been probably due to the depressive action on telluric biocenosis activity, with a slowdown of the soil organic matter mineralisation rate and a lower $\mathrm{P}$ availability. Conversely, the incorporation of residues with well-balanced $\mathrm{C} / \mathrm{N}$ can contribute to an overall increase in soil $\mathrm{P}$ soluble forms through enhanced organic P mineralisation (Randhawa et al., 2005).

The measured values of $\mathrm{P}$ content were, also in this case, in line with what reported in literature (Giannini et al., 2017).

Finally, the two different cover crops were also able to influence the biomass yield of poplar harvested in 2013 (second growing season) (Table 3), whereas no significant difference among treatments was found for plant density (ranging from 0.58 to 0.63 $\mathrm{m}^{-2}$ ). The presence of TS favoured the development of poplar

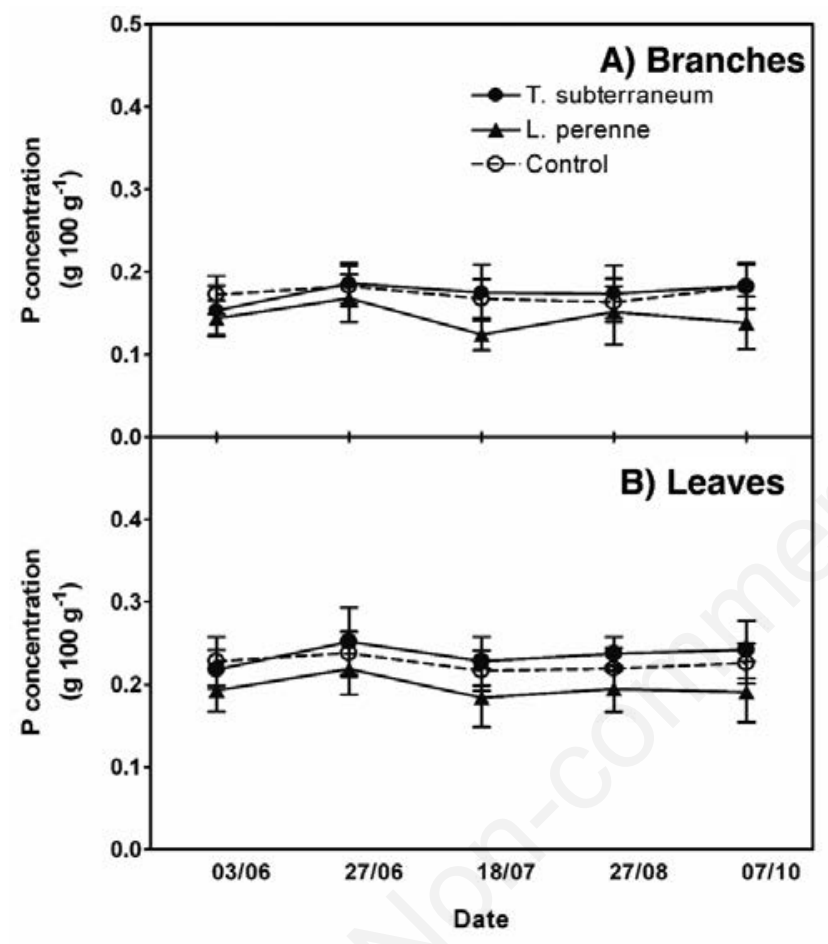

Figure 5. Phosphorous content of poplar branches (A) and leaves (B) at five different dates as affected by the soil cover type: Trifolium subterraneum (TS), Lolium perenne (LP) and the untreated control (CO). Vertical bars represent the standard errors of the mean.

Table 3. Poplar biomass production as affected by the soil cover type: Trifolium subterraneum (TS), Lolium perenne (LP) and the untreated control (CO).

\begin{tabular}{lcc} 
Soil cover type & Poplar biomass production (t d.m. ha & \\
& 2013 & 2014 \\
TS & $14.65^{\mathrm{a}}$ & $52.89^{\mathrm{a}}$ \\
LP & $10.12^{\mathrm{c}}$ & $48.66^{\mathrm{a}}$ \\
\hline CO & $13.38^{\mathrm{b}}$ & $51.20^{\mathrm{a}}$ \\
P value & 0.001 & 0.1881 \\
\hline
\end{tabular}

a-c Within each factor, letters indicate significant differences $\mathrm{P}<0.05$ (Duncan's test). plants reaching the highest yield (14.65 $\mathrm{tha}^{-1}$ of dry matter), significantly different in respect to the other two soil cover types. On the other hand, the use of LP caused a significant reduction in biomass production $\left(10.12 \mathrm{t} \mathrm{ha}^{-1}\right)$ in comparison also with the control $\left(13.38 \mathrm{tha}^{-1}\right)$. These yield levels were consistent with the findings reported by Pannacci et al. (2009) for different poplar clones under two-year harvest cycle in an inland district of Central Italy (from 10.49 to $12.86 \mathrm{t} \mathrm{ha}^{-1}$ of dry matter).

The results obtained in 2014, at the end of the third growing season (Table 3), highlighted a recovery both of the CO- and of LP-poplar, whose yield (51.20 and $48.66 \mathrm{t} \mathrm{ha}^{-1}$ of dry matter, respectively) was statistically equivalent to that of the TS $(52.89 \mathrm{t}$ $\mathrm{ha}^{-1}$ ). These levels of poplar biomass production were comparable with those obtained by other Authors in the same area (Nassi o di Nasso et al., 2010).

The reasons behind the positive effects of TS on poplar yield could be found in the different availability of nutrients in the soil layer mostly explored by the roots $(0.00-0.30 \mathrm{~m})$ and, consequently, in the higher poplar nutrient uptake, as proved by the higher TS values of nutrient concentration in leaves and branches. The yield gap of the LP can be related instead to the negative effect that the addition of high $\mathrm{C}: \mathrm{N}$ biomass to the soil had on the activity of the telluric biocenosis reducing the nutrient availability for plants. In literature, there are studies that confirmed (Coleman et al., 2006; Stolarski et al., 2015) or denied (Liberloo et al., 2006; Ceotto et al., 2016) the effect of nutrient supply on poplar yield. These differences are presumably to put in relation to different fertility condition of the soil where the research activities have been carried out (Moscatelli et al., 2008).

The effect of cover type on soil water content seemed to not affect poplar yield since it was limited to particular conditions with occurrence of high temperatures and rainstorms. Indeed, the monitored values of soil humidity were very similar between the two cover crop treatments, whereas the yield results were significantly different.

The yields of the third growing season were unaffected by soil cover type treatments (Table 3 ). This result could be explained with the higher competition level exerted by the T. subterraneum, the most developed cover, on the poplar re-sprouting in the early spring of 2014. Anyway, this effect was short lasting because the poplar growing dominated soon all the cover crops, whose development was substantially stopped with the closure of inter-row spaces by the poplar crown. Therefore, the cover crops failed to thrive in the years following their sowing despite the choice of short harvest-cycle for poplar (2 years). The objective of long-lasting permanence of cover crops in SRC seems thus hard to achieve with the use of traditional SRC planting distances.

\section{Conclusions}

The biomass produced by the cover crops intercropped with poplar was considerable and it can be considered useful to maintain an adequate soil cover and organic matter content during the first year of poplar establishment. The use of T. subterraneum can represent a promising option to increase soluble nitrogen availability in the soil without using any mineral fertiliser, and to favour biomass production of poplar plants under limited soil fertility conditions. The introduction of $L$. perenne played instead a negative role on poplar nutrient uptake and could be recommended only if sown in mixtures with legume species.

During the summer, the presence of cover crop residues 
ensured a higher soil humidity in comparison with the untreated control but without significant differences between the two cover crop species tested. For these reasons, the yield gap of LP-poplar in our study can be essentially attributed to the addition to the soil of a biomass with a high $\mathrm{C}: \mathrm{N}$ ratio, which depressed the telluric biocenosis activity reducing the nutrient availability for plants.

The satisfactory yields achieved proved that intercropping was well tolerated by poplar provided that the interspecific competition level is minimised by shifting both poplar and cover crop establishment. In addition, the choice of a high plant density for SRC can contribute to reduce the interspecific competition.

The goal to keep growing cover crops in SRC intercropping beyond the first growing season is hard to achieve, unless we decide to modify deeply the SRC system management by increasing the traditional planting distances and by shortening furthermore the harvest cycle. These options could make sense only in the perspective to transform the SRCs in real agro-forestry systems.

\section{References}

Aronsson H, 2000. Nitrogen Turnover and Leaching in Cropping Systems with Ryegrass Catch Crops. Doctoral thesis, University of Agricultural Sciences Uppsala, Sweden.

Bergante S, Zenone T, Facciotto G, 2015. In: Bhardwaj AK, Zenone T, Chen J, (Eds.), Sustainable biofuels. An ecological assessment of the future energy. Walter de Gruyter $\mathrm{GmbH} \&$ Co, Berlin, Germany, pp. 137-154.

Berthrong ST, Buckley DH, Drinkwater LE, 2013. Agricultural management and labile carbon additions affect soil microbial community structure and interact with carbon and nitrogen cycling. Microb. Ecol. 66:158-70.

Blanco-Canqui H, Shaver TM, Lindquist JL, Shapiro CA, Elmore RW, Francis CA, Hergert GW, 2015. Cover crops and ecosystem services: insights from studies in temperate soils. Agron. J. 107:24-49.

Bremner J, 1965. Total nitrogen. Methods of soil analysis. Part 2. Chem. Microbiol. Prop. 1149-78.

Ceotto E, Castelli F, Moschella A, Diozzi M, Di Candilo M, 2016. Poplar short rotation coppice is not a first choice crop for cattle slurry fertilisation: biomass yield and nitrogen-use efficiency. Ind. Crop. Prod. 85:167-73.

Cohan J, Bouthier A, Labreuche J, Justes E, 2014. Leguminous cover-crops effects compared to non-leguminous on nitrate leaching and nitrogen supplying to the succeeding corn and spring barley. In: C.M.dS. Cordovil (Ed.), Proc. of the 18th Nitrogen Workshop - The nitrogen challenge: building a blueprint for nitrogen use efficiency and food security. Lisboa, Portugal, pp. 400-401.

Coleman M, Tolsted D, Nichols T, Johnson WD, Wenee EG, Houghtaling T, 2006. Post-establishment fertilisation of Minnesota hybrid poplar plantations. Biomass Bioenerg. 30:740-9.

Corre-Helloua G, Dibeta A, Hauggaard-Nielsenb H, Crozata Y, Goodingc M, Ambusb P, Dahlmannd C, von Fragsteind P, Pristeri A, Monti M, Jensen ES, 2011. The competitive ability of pea-barley intercrops against weeds and the interactions with crop productivity and soil $\mathrm{N}$ availability. Field Crops Res. 122:264-72.

Dimitriou I, Busch G, Jacobs S, Schmidt-Walter P, Lamersdorf N, 2009. A review of the impacts of Short Rotation Coppice cultivation on water issues. Agric. Forest. Res. 59:197-206.
Frenda AS, Di Grigoli A, Bonanno A, Giambalvo D, 2009. Valutazione dell'adattabilità, produttività e persistenza di alcune leguminose annuali autoriseminanti in ambiente mediterraneo. In: Azioni di innovazione e ricerca a supporto del piano proteine vegetali. Leguminose autoriseminanti. CRPA Spa, Reggio Emilia, Italy, pp. 1-10.

Giannini V, Pistocchi C, Silvestri N, Volterrani M, Cantini V, Bonari E. 2015. Preliminary investigation on the potential use of two C4 turfgrass species to reduce nutrient release in a Mediterranean drained peatland. Environ. Sci. Pollut. Res 22:2396-405.

Giannini V, Silvestri N, Dragoni F, Pistocchi C, Sabbatini T, Bonari E, 2017. Growth and nutrient uptake of perennial crops in a paludicultural approach in a drained Mediterranean peatland. Ecol. Engine. 103:478-87.

Gomez KA, Gomez AA, 1984. Statistical procedures for agricultural research. John Wiley \& Sons, USA.

Hytönen J, 1995. Ten-year biomass production and stand structure of Salix "Acquatica" energy forest plantation in southern Finland. Biomass Bioenerg. 8:63-71.

Kauter D, Lewandowski I, Claupein W, 2003. Quantity and quality of harvestable biomass from Populus short rotation coppice for solid fuel use - a review of the physiological basis and management influences. Biomass Bioenerg. 24:411-27.

Lal R, 2009. Soils and food sufficiency. A review. Agron. Sustain. Dev. 29:113-33.

Laloy E, Bielders CL, 2010. Effect of Intercropping Period Management on Runoff and Erosion in a Maize Cropping System. J. Environ. Qual. 39:1001-8.

Langeveld H, Quist-Wessel F, Dimitriou I, Aronsson P, Baum C, Schulz U, Bolte A, Baum S, Köhn J, Weih M, Gruss H, Leinweber P, Lamersdorf N, Schmidt-Walter P, Berndes G, 2012. Assessing environmental impacts of short rotation coppice (SRC) expansion: model definition and preliminary results. Bioenerg. Res. 5:621-35.

Laureysens I, Bogaert J, Blust R, Ceulemans R, 2004. Biomass production of 17 poplar clones in a short-rotation coppice culture on a waste disposal site and its relation to soil characteristics. Forest Ecol. Manag. 187:295-309.

Liberloo M, Calfapietra C, Lukac M, Godbold D, Luo ZB, Polle A, Hoosbeek MR, Kull O, Marek M, Raines C, Rubino M, Taylor G, Scarascia Mugnozza G, Ceulemans R, 2006. Woody biomass production during the second rotationof a bio-energy Populus plantation increases in a future high $\mathrm{CO}_{2}$ world. Global Change Biol. 12:1094-106.

Malik RK, Green TH, Brown GF, Mays D, 2000. Use of cover crops in short rotation hardwood plantations to control erosion. Biomass Bioenerg. 18:479-87.

Mazzoncini M, Sapkota TB, Bàrberi P, Antichi D, Risaliti R, 2011. Long-term effect of tillage, nitrogen fertilisation and cover crops on soil organic carbon and total nitrogen content. Soil Till. Res. 114:165-74.

Moscatelli MC, Lagomarsino A, De Angelis P, Grego S, 2008. Short- andmedium-term contrasting effects of nitrogen fertilisation on $\mathrm{C}$ and $\mathrm{N}$ cycling in a poplar plantation soil. For. Ecol. Manage. 255:447-54.

Munkholm LJ, Hansen EM, 2012. Catch crop biomass production, nitrogen uptake and root development under different tillage systems. Soil Use Manage. 28:517-29.

Nassi o di Nasso N, Guidi W, Ragaglini G, Tozzini C, Bonari E, 2010. Biomass production and energy balance of a 12 -year-old short-rotation coppice poplar stand under different cutting cycles. GCB Bioenergy 2:89-97. 
Nicholls C, Altieri M, 2012. Plant biodiversity enhances bees and other insect pollinators in agroecosystems. A review. Agron. Sustain. Dev. 33:1-18.

Nisbet T, Thomas H, Shah N, 2011. Short Rotation Forestry and Water. In: H. McKay, (Ed.), Short rotation forestry: review of growth and environmental impacts. Forest Research Monograph, 2. Forest Research, Surrey, UK, pp. 13-36.

Otto D, Loddo D, Zanin G, 2010. Weed-poplar competition dynamics and yield loss in Italian short-rotation forestry. Weed Res. 50:153-62.

Pannacci E, Bartolini S, Covarelli G, 2009. Evaluation of four poplar clones in a short rotation forestry in Central Italy. Ital. J. Agron. 4:191-8.

Pellis A, Laureysens I, Ceulemans R, 2004. Growth and production of a short rotation coppice culture of poplar I. Clonal differences in leaf characteristics in relation to biomass production. Biomass Bioenerg. 27:9-19.

Quemada M, Baranski M, Nobel-de Lange MNJ, Vallejo A, Cooper JM, 2013. Meta-analysis of strategies to control nitrate leaching in irrigated agricultural systems and their effects on crop yield. Agr. Ecosyst. Environ. 174:1-10.

Randhawa PS, Condron LM, Di HJ, Sinaj S, McLenaghen RD, 2005. Effect of green manure addition on soil organic phosphorus mineralisation. Nutr. Cycl. Agroecosyst. 73:181-9.

Roedl A, 2010. Production and energetic utilisation of wood from short rotation coppice - a life cycle assessment. Int. J. Life Cycle Assess. 15:567-78.

Rowe RL, Street NR, Taylor G, 2009. Identifying potential environmental impacts of large-scale deployment of dedicated bioenergy crops in the UK. Renew. Sust. Energ. Rev. 13:271-90.

Sapkota TB, Mazzoncini M, Barberi P, Antichi D, Silvestri N,
2012. Fifteen years of no till increase soil organic matter, microbial biomass and arthropod diversity in cover crop-based arable cropping systems. Agron. Sustain. Dev. 32:853-63.

Silvestri N, Risaliti R, Ginanni M, Pampana S, 2001. La valutazione del deflusso di superficie in sistemi colturali di pianura: alcune esperienze svolte in provincia di Pisa. Riv. Irrig. Drenag. 48:36-42.

Smith MS, Frye WW, Varco JJ, 1987. Legume winter cover crops. Adv. Soil Sci. 7:95-139.

Stolarski MJ, Krzy`zaniak M, Waliszewska B, Szczukowski S, Tworkowski J, Zborowska, M, 2013. Lignocellulosic biomass derived from agricultural land as industrial and energy feedstock. Drewno. Pr. Nauk. Donies. Komunik 189, 56:5-23.

Stolarski MJ, Krzy'zaniak M, Szczukowski S, Tworkowski J, Załuski D, Bieniek A, Gołaszewski J, 2015. Effect of increased soil fertility on the yield andenergy value of short-rotation woody crops. Bioenergy Res. 8:1136-47.

Talamucci P, 2002. Trifoglio sotterraneo. In: Baldoni R, Giardini L, (Eds), Coltivazioni erbacee. Foraggere e tappeti erbosi. Pàtron Editore, Bologna, Itay, pp. 153-159.

Vanguelova E, Pitman R, 2011. Impacts of Short Rotation Forestry on Soil Sustainability. In: H. McKay (Ed.), Short Rotation Forestry: review of growth and environmental impacts. Forest Research Monograph, 2. Forest Research, Surrey, UK, pp. 37-79.

White RE, Helyar KR, Ridley AM, Chen D, Heng LK, Evans J, 2000. Soil factors affecting the productivity and sustainability of perennial and annual pastures in the high rainfall zone of South-Eastern Australia. Aust. J. Agric Exp. 40:267-83.

Willey RW, 1979. Intercropping - Its importance and research needs. Field Crop Abstr. 32:1-10. 